\title{
Hubungan Perilaku Pencarian Informasi dengan Penggunaan "Line" Dakwah Islam
}

\author{
${ }^{1}$ Balqis Annisa Ramdhani, ${ }^{2}$ Prijana, ${ }^{3}$ Saleha Rodiah \\ Program Studi Ilmu Perpustakaan, Fakultas Ilmu Komunikasi, Universitas Padjadajaran, Jatinangor \\ E-mail: 'balqisannisa22@gmail.com, ${ }^{2}$ prijanafikom@gmail.com, ${ }^{3}$ saleha.rodiah@yahoo.com
}

\begin{abstract}
Abstrak. Kegiatan pencarian informasi merupakan kegiatan yang sering dilakukan dan dengan berkembangnya teknologi informasi dan komunikasi kegiatan ini dapat dilakukan pada media yang lebih canggih seperti media sosial line. Penelitian ini bertujuan untuk mengetahui hubungan perilaku pencarian informasi mahasiswa anggota Syamil Unpad melalui penggunaan official account line dakwah Islam berdasarkan teori Krikelas. Tindakan perilaku pencarian informasi diawali adanya kebutuhan yang dilandasi oleh suatu aktivitas kegiatan ataupun kebutuhan dilingkungan sekitarnya. Dengan tiga tahapan perilaku pencarain informasi yaitu dorongan kebutuhan informasi, menciptakan perubahan dan aktivitas lingkungan. Penelitian ini menggunakan metode studi kuantitatif korelasional dengan jumlah populasi 250. Teknik pengumpulan data menggunakan kuisioner, obsevasi, wawancara dan studi kepustakaan. Penyebaran kuisioner dilakukan dengan cara mengirimkan link kuisioner yang telah dibuat melalui aplikasi Google Form pada seluruh anggota Syamil Unpad. Hasil dari penelitian menunjukkan perilaku pencarian informasi mahasiswa memilki hubungan yang cukup berarti dengan penggunaan official account line Dakwah Islam, dorongan kebutuhan informasi memilki hubungan yang rendah dengan penggunaan official account line Dakwah Islam, menciptakan perubahan memiliki hubungan yang cukup berarti dengan penggunaan official account line Dakwah Islam dan aktivitas lingkungan memiliki hubungan yang kuat dengan penggunaan official account line Dakwah Islam.
\end{abstract}

Kata kunci: anggota syamil unpad, official account line dakwah Islam, perilaku pencarian informasi

Abstract. Information seeking activity is a frequent activity and with the development of information and communication technology this activity also can be done on sophisticated media such as social media line. This study aims to determine the relationship of information seeking behavior of Unpad Syamil students through the use of official account line of Islamic propaganda based on Krikelas theory. Action information seeking behavior begins the need based on an activity or the needs of the surrounding environment. With three stages of information seeking behavior that is; a boost of information needs, creating changes and environmental activities. This research uses correlational quantitative method with 250 populations. Data collecting technique using questionnaire, observation, interview and literature study. The distribution of questionnaires is done by sending a questionnaire link that has been created through the Google Form application to all members of Unpad Syamil. The result of the research shows that the student's information seeking behavior has a significant relationship with the use of the line official account of Islamic Da'wah, the impetus of information needs has a low relationship with the use of the line official account of Islamic Da'wah, creating the change has a significant relationship with the use of official account line Islamic Da'wah and environmental activities have a strong relationship with the use of line official account of Islamic Da'wah.

Keywords: members of syamil unpad, official account line Islamic da'wah, information seeking behavior 


\section{PENDAHULUAN}

Dalam berbagai kalangan dan latar belakang pendididkan, pasti setiap orang pernah melakukan kegiatan mencari informasi dengan latar belakang dan tujuan yang berbeda. Namun, kegiatan mencari informasi bukan lagi suatu hal yang asing untuk seorang mahasiswa.

Dalam pencarian informasi terlebih dahulu mengerti tentang makna dari informasi. Secara etimologi kata informasi berasal dari kata bahasa Prancis kuno (1387) 'informacion', mengambil dari istilah bahasa latin yaitu information yang berarti "konsep ide atau garis besar", informasi ini merupakan kata benda dari informare yang berarti aktivitas-aktivitas dalam pengetahuan yang dikomunikasikan.

Seperti dalam penjelasan Pendit (2003) yang mengulas dan mengembangkan teori Wilson (2000), perilakuinformasimerupakankeseluruhan perilaku yang berkaitan dengan sumber dan saluran informasi, termasuk perilaku pencarian dan penggunaan informasi, baik secara aktif maupun secara pasif.

Untuk pengertian perilaku informasi lebih sempit lagi, maka perilaku pencarian informasi adalah kegiatan seseorang (mahasiswa) yang dilakukan untuk memeroleh informasi guna memenuhi kebutuhannya.

Perilaku pencarian informasi ini dimulai ketika mahasiswa atau seseorang merasa bahawa dirinya kurang akan pengetahuan yang dimilkinnya, untuk memenuhi kebutuhan akan pengetahuan, maka seseorang itu akan langsung melakukan tindakan pencarian informasi yang disebut dengan perilaku pencarian informasi. Tindakan menggunakan literatur adalah suatu perilaku yang kenyataannya menggambarkan berbagai tujuan (Krikelas dalam Suwanto, 1997: 21-22). Bila dihubungkan dengan informasi, berarti perilaku informasi adalah segala sesuatu yang dilakukan atau dialami seseorang terhadap informasi. Seperti mencari, menemukan, mengunduh, menggunakan, dan meneruskan informasi.

Pada saat ini, menurut Syafii (2012), dalam penelitian sebelumnya mengenai informasi sesuai dengan kualitasnya, dapat mempengaruhi cara berpikir dan permasalahan perpecahan dalam satu agama dapat ditimbulkan dari informasi yang diperoleh oleh pengguna saat informasi tersebut dijadikan sebagai landasan berpikir, maka perilaku pencarian informasi ini sangat penting untuk mengetahui bagaimana cara atau langkah-langkah, khususnya anggota Syamil Unpad, dalam mendapatkan informasi yang telah diperolehnya, karena perilaku pencarian informasi dilatarbelakangi oleh aktivitas yang dilakukan oleh pencari informasi tersebut.

Pada era teknologi yang semakin berkembang, kegiatan pencarian informasi bukan hanya dilakukan dengan media buku, tetapi juga dapat menggunakan media online seperti internet, dan aplikasi yang terhubung dengan interenet salah satunya adalah line, Media sosial line merupakan media komunikasi yang sangat populer di kalangan mahasiswa, tampilan yang menarik dan berbagai macam fitur yang disediakan oleh line dapat menjadi daya tarik bagi mahasiswa untuk menggunakan media sosial ini.

Official Account Dakwah Islam merupakan account LINE sumber informasi dalam bentuk sistem teknologi, kemudahan dan kecepatan dalam mendapatkan informasi mengenai ilmu agama Islam dengan mudah, pemilihan account Dakwah Islam ini karena seorang pendiri dari account ini adalah mahasiwa alumni dari lingkungan unpad, dan official account Dakwah Islam merupakan salah satu account mengenai informasi agama Islam yang jumlah untuk saat ini bulan Januari tahun 2017, yaitu 2.018.843 dengan jumlah postingan atau informasi yang telah disebar berjumlah 19.610 postingan.

Informasi agama Islam merupakan informasi yang sangat penting dan harus 
akurat, di mana penerima dari informasi tersebut dapat mengimplementasikan atau mengaplikasikan informasi yang telah diperoleh untuk digunakan pada kehidupan sehari-hari, sehingga bila informasi yang disebarkan tidak sesuai dengan al-Quran dan hadis akan berakibat kesalah pahaman dan perpecahan antara umat islam sendiri.

Dalam penambahan pengetahuan atau informasi pasti diperlukannya pencarian informasi tersebut untuk memperoleh dan menghasilkan hasil informasi yang sesuai dengan kebutuhan pengguna terutama mahasiswa dalam objek penelitian ini. Sesuai dengan model teori perilaku pencarian informasi dari Krikelas (1983) mengatakan bahwa tindakan pencarian informasi diawali oleh adanya kebutuhan yang dilandasai oleh suatu aktivitas kegiatan ataupun kebutuhan yang dilandasi oleh suatu aktivitas kegiatan ataupun kebutuhan di lingkungan sekitarnya. Informasi dicari atau dibutuhkan untuk melakukan perubahan dalam diri, bukankah ketika seseorang ingin menjadi lebih baik dalam sholat dia harus mengetahui cara ibadah shalat yang baik itu seperti apa, untuk mengetahui caranya maka sesorang itu akan mencari informasi yang sesuai dengan kebutuhannya.

Aktivitas lingkungan, memengaruhi perilaku pencarian informasi apabila sesorang berada dilingkungan agama, kemungkinan besar informasi yang akan dicaripun menganai informasi agama atau ilmu pengetahuan agama, maka perilaku pencarian informasi mahasiwsa anggota Syamil Unpad dengan pengunaan official account line Dakwah Islam sebagai pemenuhan kebutuhan informasi merupakan hubungan yang berekaitan untuk diteliti.

Berdasarkan uraian di atas tujuan dari penelitian ini adalah: (1) untuk mengetahui hubungan perilaku pencarian informasi pada mahasiswa unpad dengan penggunaan official account line Dakwah Islam; (2) untuk mengetahui hubungan dorongan kebutuhan informasi pada mahasiswa unpad dengan penggunaan official account line Dakwah Islam; (3) untuk mengetahui hubungan menciptakan perubahan pada mahasiswa dengan penggunaan official account line Dakwah Islam; (4) untuk mengetahui hubungan aktivitas di lingkungan pada mahasiswa dalam penggunaan official account line Dakwah Islam.

\section{Informasi}

Informasi adalah suatu rekaman fenomena yang diamati, atau bisa juga berupa putusan-putusan yang dibuat seseorang (Eastbrook dalam Pawit, 2012). Ada peristiwa atau adanya kejadian disitu bisa lahir informasi, artinya kejadian atau peristiwa apa pun bisa melahirkan informasi, terutama jika direkam atau dilihat orang. Suatu peristiwa atau kejadian apa pun, jika tidak pernah dilihat atau direkam oleh seseorang, tidak akan menjadi informasi, begitupula dengan informasi yang disimpan di tuliskan dalam buku atau benda yang dapat meberikan informasi.

Informasi lebih sering diartikan sebagai hasil dari suatu pengetahuan, bahwa produk dari informasi itu adalah pengetahuan, pengertian informasi menurut sumber-sumber informasi denotatif. Kamus Encarta (2009) memberi makna informasi sebagai berikut: (1) Pengetahuan,yakni pemerolehan pengetahuan secara tegas, pemasokan sesuatu, mendapatkan sesuatu. (2) Pemerolehan fakta, kumpulan fakta atau data mengenai subjek tertentu. (3) Layanan informasi telepon, yakni layanan telepon yang memberikan informasi nomor-nomor telepon atau infomasi lain atas dasar permintaan publik (4) Membuat fakta menjadi diketahui, komunikasi tentang fakta dan pengetahuan.(5). Data komputer yang terorganisasikan, bahan-bahan yang memiliki arti yang berasal dari data komputer dengan cara mengorganisasikannya dan menginterpretasikannya, atau data dari 
proses pengolahan komputer setelah diinterpretasikan maknanya.

Menurut McLeod (dalam Yakub, 2012:8) informasi adalah data yang diolah menjadi bentuk lebih berguna dan lebih berarti bagi yang memerlukan. Informasi juga disebut data yang diproses atau data yang memiliki arti. Informasi merupakan data yang telah di proses sedemikian rupa sehingga meningkatkan pengetahuan seseorang yang menggunakan. Para pembuat keputusan memahami bahwa informasi menjadi faktor kritis dalam menentukan kesuksesan atau kegagalan dalam suatu bidang usaha. Sistem apapun jangan ada informasi tidak akan berguna, karena sistem tersebut akan mengalami kemacetan dan akhirnya berhenti. Informasi dapat berupa data mentah, dapat tersusun, kapasitas sebuah saluran informasi, dan sebagainya. Hubungan antara data informasi digambarkan pada Gambar 1.

\section{Perilaku Pencarian Informasi}

Perilaku berasal dari kata "peri" dan "laku". Peri berarti cara berbuat kelakuan perbuatan dan laku berarti perbuatan, kelakuan, cara menjalankan. Belajar dapat didefinisikan sebagai suatu proses dimana suatu organisasi berubah perilakunya, sebagai akibat pengalaman.

Para psikolog mengemukakan bahwa perilaku terbentuk dari adanya

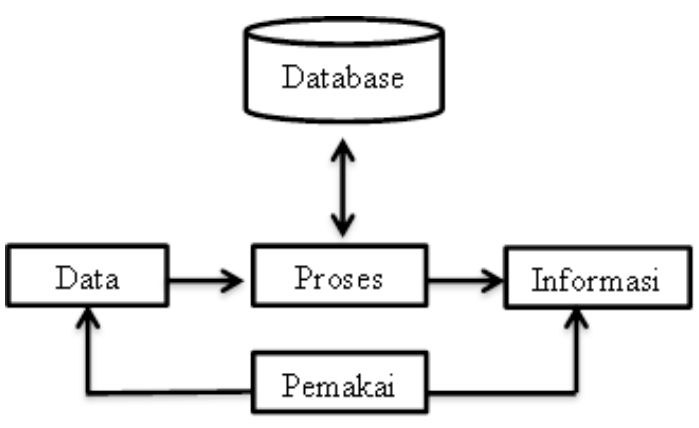

(Sumber: Abdul Kadir,2003)

GAMBAR 1. Pemerosesan Data menjadi Informasi interaksi antara domain trikomponen sikap yakni interaktif antara komponen kognitif, afektif dan domain konatif. Namun masih terdapat kekeliruan yang menganggap komponen konatif salah satu komponen dalam trikomponen sikap sebagai perilaku (behaviour), sehingga perilaku dianggap sebagai salah satu komponen sikap (atitude).

Para psikolog telah membedakan perilaku dan sikap sebagai dua gejala yang dapat berbeda satu sama lainnya. Lapiere telah meneliti dan menghasilkan poskulat variasi independent, intitemen yang dijelaskan dengan konsep adalah bahwa sikap dan perilaku merupakan dimensi dalam diri individu yang berdiri sendiri, terpisah dan berbeda.

Pemikirin ini didukung oleh Muler yang berpendapat bahwa, Komponen konatif dalam tiga komponen sikap tidak disamakan dengan perilaku. Komponen konatif merupakan baru sebatas kecenderungan perilaku yang terkristalisasi dalam kata akan, mau dan hendak. Sedangkan perilaku merupakan suatu bentuk tindakan nyata dari individu yang dapat diukur dengan panca indera langsung. Dengan demikian, Mueler menegaskan bahwa makna behaviour adalah perilaku aktual sedangkan makna konatif adalah trikomponen sikap sebagai "kecenderungan perilaku". Pemikiran ini menunjukkan bahwa komponen konatif dalam trikomponen sikap hanyalah salah satu penyebab pembentukan perilaku aktual

Pencarian infromasi adalah kegiatan seseorang yang dilakukan untuk mendapatkan informasi. Sesorang akan menunjukkan perilaku pencarian informasi untuk memenuhi kebutuhannya.

Berdasarkan latar belakang yang telah di urai bahawa perilaku pencarain informasi adalah segala bentuk kegiatan yang dilakukan atau dialami, perilaku yang dapat mengahasilkan suatu informasi, seperti kegiatan mencari, menemukan, mengunduh, menggunakan, dan meneruskan informasi. 
Seperti yang telah dijelaskan oleh Pendit (2003) yang mengulas dan mengembangkan teori dari Wilson (2000), perilaku informasi merupakan keseluruhan kegiatan dan perilaku manusia yang berkaitan dengan sumber dan saluran informasi, termasukperilaku pencarian dan penggunaan informasi baik secara aktif maupun pasif.

Untuk penjelasan lebih sempitnya lagi, bahwa perilaku pencarian informasi ini adalah kegiatan sesorang yang dilakukan untuk mendapatkan informasi. Manusia akan menunjukkan perilaku pencarian informasi untuk memenuhi kebutuhan hidupnya.

Teori yang digunakan dalam penelitian ini untuk independen perilaku pencarian informasi yaitu menggunakan teori Krikelas yang bersumber dari buku Meho yang bejudul "Modeling the Information Seeking Behavior of Social Scientists 2003". Asumsi dari teori ini adalah tindakan pencarian informasi diawali oleh adanya kebutuhan yang dilandasi oleh suatu aktivitas kegitan ataupun kebutuhan di lingkungan sekitarnya. Model Krikelas terdiri atas tiga belas komponen (Gambar 2). Proses model perilaku pencarian informasi Krikelas dimulai dari atas kebawah pada gambar model Krikelas. Komponen paling atas dari model Krikelas adalah tindakan pengumpulan informasi dan pemberian informasi. Hasil dari pengumpulan informasi diarahkan untuk disimpan dalam memori, observasi langsung dan data pribadi. Tindakan pemberian informasi di dasarkan pada sumber internal dan eksternal dibagi menjadi dua komponen yaitu "kontak langsung" dan "rekam". Adapun komponen "kontak langsung" tersebut adalah hubungan tatap muka anatar interpersonal seperti telepon, video call, email, dan lain-lain yang menghubungkan dua arah secara interpersonal. Sedangkan komponen rekam yaitu berupa literatur seperti buku dan jurnal (Case, 1981:119).

Tetapi Model Krikelas ini tidak membatasi hanya untuk satu jenis pekerjaan dalam pencarian informasi. Untuk model ini pengumpulan informasi memang memilki tujuan yang lebih umum,

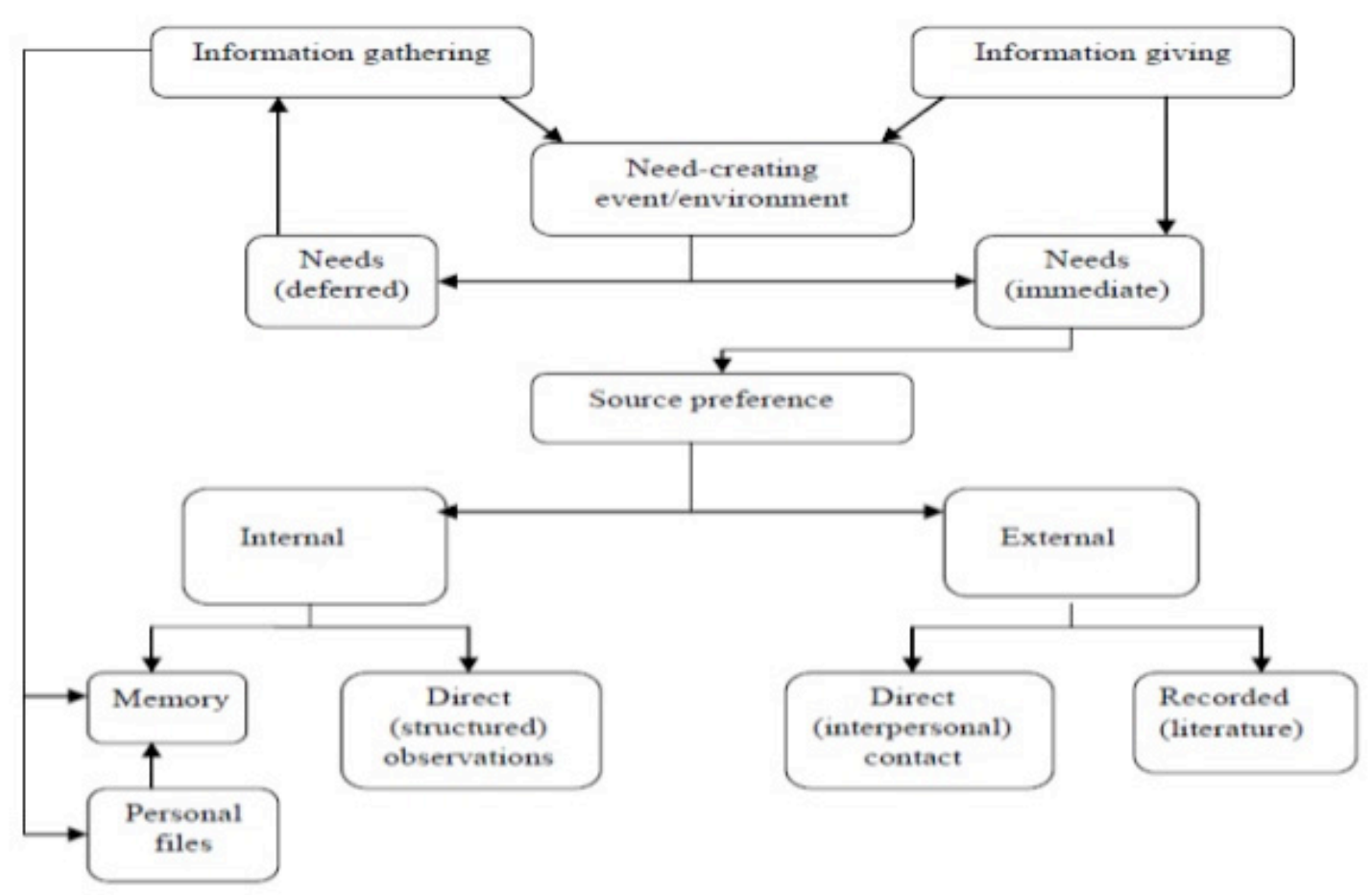

GAMBAR 2. Model Looking for Information oleh Krikelas (2003: 120) 
sama seperti sebelumnya pengumpulan informasi muncul disebabkan oleh lingkungan atau kejadian sehingga menimbulkan suatu kebutuhan.

Krikelas (1983) mengatakan bahwa tindakan pencarian informasi diawali oleh adanya kebutuhan yang dilandasi oleh suatu aktivitas kegitan ataupun kebutuhan dilingkungan sekitarnya. Membedakan dua jenis kebutuhan yaitu kebutuhan yang bersifat segera dan kebutuhan yang bersifat ditunda. Krikelas memahami informasi sebagai stimulan yang menciptakan ketidakpastian yang membuat sesorang sadarakan kebutuhannya dan menciptakan suatu perubahan dalam tingkatan tertentu. Bahwa informasi dapat mempengaruhi pemakai, karenanya semakin jelas bahwa gagasan Krikelas mengaitkan informasi dengan rasa ketidakpastian diri dalam diri seseorang. Ras inilah yang mendorong seseorang untuk mencari informasi. Jadi dapat dikatakan bahwa jika seorang membutuhkan informasi, maka informasi tersebut merupakan stimulan terhadap ketidakpastian (Prijana, 262-263:2016).

Penggunaan official account Dakwah Islam merupakan media dalam melakukan pencarian informasi, yang dapat diartikan bawah official account Dakwah Islam ini adalah pemberi informasi sebagai pemenuhan kebutuhan informasi bagi para pengguna official account Dakwah Islam. Penggunaan berdasarkan intensitas mengakses, macam isi yang tersedia, dan sebagai sumber informasi bagi para pengguna.

Menurut morgan dan King dalam Wilson (1996) mengemukakan bahwa jenis kebutuhan informasi muncul dari tiga motif, yaitu: (1) Physiological motives, kebutuhan informasi didasari atas kebutuhan diri sendiri. (2) Unlearned motives, kebutuhan informasi terjadi karena adanya tugas, atau informasi digunakan untuk mengambil suatu keputusan, (3) Social motives, kebutuhan informasi terjadi adanya permintaan informasi dari orang lain.
Sesuai dengan penjelasan mengenai kebutuhan dan berdasarkan teori kebutuhan, dalam penelitian ini akan membahas mengenai sejauh mana official account dakwah Islam sebagai pemberi informasi dalam memenuhui kebutuhan informasi pengguna atau followersnya terutama pada mahasiswa Unpad, khususnya anggota Syamil Unpad.

\section{METODE}

\section{Populasi dan Teknik Pengambilan Sampel}

Jumlah popoulasi dalam penelitian ini berjumlah 250 dengan sampel 152, Teknik sampling yang digunakan dalam penelitian ini adalah sampling peluang (probability sampling) karena diketahui jumlah populasi secara pasti, dan jenis sampling acak sederhana (simple random sampling) teknik pengambilan sampel menggunakan rumus :

$$
\mathrm{n}=\frac{n_{0}}{1+\left(\frac{n_{0}}{N}\right)} \quad \mathrm{n}_{0}=\frac{t^{2} \cdot(p \cdot q)}{d^{2}}
$$

Notasi :

$\mathrm{n}=$ Sampel (size of simple)

$\mathrm{n} 0=$ Sampel asumsi

$\mathrm{t}=$ Koefisien kepercayaan (coefficient of confidence)

$\mathrm{d}=$ Sampling error

$\mathrm{p} \& \mathrm{q}=$ Parameter proposi binomial

$\mathrm{N}=$ Populasi (size of population)

Jumlah populasi adalah 250 dengan tingkat kepercayaan 95\%, maka koefisien kepercayaan 1,96, jumlah sampel yang dikehendaki adalah :

$$
\begin{array}{rll}
\mathrm{n}_{0} & =\frac{(1,96)^{2} \cdot(0,50) \cdot(0,50)}{(0,5)^{2}} \\
\mathrm{n} & =\frac{384}{1+\left(\frac{384}{250}\right)} & =\frac{384}{2,536} \\
& =\frac{0,9604}{0,0025} & =151,4 \approx 152
\end{array}
$$


Jadi jumlah sampel dalam penelitian ini berjumlah 152 orang atau responden.

\section{Jenis dan Sumber Data}

Dalam penelitian ini terdapat 2 data yaitu data primer dan data sekunder. Data primer diperoleh dari hasil kuisioner yang dibagikan kepada responden, dan melakukan wawancara. Data sekunder diperoleh dari studi pustaka buku.

\section{Uji Validitas dan Realibitas}

Uji validitas yang dilakukan pada penelitian ini menggunakan analisis Korelasi Pearson Product Moment dengan rumus sebagai berikut:

$$
\alpha=\left[\frac{k}{k-1}\right]\left[1-\frac{\sum S_{J^{2}}}{S_{S^{2}}}\right]
$$

Realibitas menggunakan Alpha Cronbach dengan menggunakan rumus sebagai berikut (Siregar, 2011,175) :

\section{Nilai Sig. $\leq \alpha$}

$$
\mathrm{r}=\frac{n \sum X Y-\sum X \sum Y}{\left.\sqrt{\left[n \sum X^{2}\right.}-\left(\sum X\right)^{2}\right]\left[n \sum Y^{2}-\left(\sum Y\right)^{2}\right.}
$$

Setelah diketahui jumlah $r_{\text {hitung }}$ dari setiap item data pada penelitian dalam kuesioner, kemudian diteruskan dengan melakukan $r_{\text {hitung }}$ dari setiap tiap item yang bersangkutan dengan $r_{\text {tabel}}$, dengan ketentua $\mathrm{dk}=\mathrm{n}-2(\mathrm{n}=$ jumlah sampel -2 ) sehingga didaptkan $\mathrm{dk}=$ $30-2=28$ dengan taraf kepercayaan $95 \%$ atau $\alpha=0,05$ (yang ditentukan oleh peneliti) kemudian diketahui rtabel 28 sebesar 0,374 . Selanjutnya dapat ditarik kesimpulan bahwa, jika $\mathrm{r}_{\text {hitung }}>\mathrm{rt}_{\text {abel }}$ maka dinyatakan pernyataan yang dibuat dinyatkan valid, tetapi jika $r_{\text {hitung }}<r_{\text {tabel }}$ maka dinyatakan pernyataan yang dibuat dinyatakan tidak valid.

\section{Teknik Analisis Data}

Berdasarkan tujuan penelitian, kerangka konseptual penelitian dan hipotesis maka analisis yang diperlukan meliputi analisi korelasional.
Analisis hubungan korelasi dengan metode korelasi Person Product Moment (r). Metode ini dikemukan oleh Karl Person Tahun 1900. Kegunaan dari metode ini untuk mengetahui derajat hubungan dan kontribusi variabel bebas (independen) dengan varibel terikat (dependen), sehingga skala yang digunakan untuk menggunakan Person Product Moment harus interval, jika data yang dimilki adalah data ordinal maka harus dinaikan terlebih dahulu ke skala interval, menggunakan MSI (Method of successive intervals) dengan menggunakan program komputer (Addins Microsoft Excel dengan STAT97. xla) (Prijana, Winoto, \& Yanto, 2016).

Harga koefisien korelasi berada pada renatang berikut : $(-1 \leq \mathrm{r} \leq+1)$. Apabila nilai $r=-1$ artinya korelasinya negatif sempurna; $r=0$ artinya tidak ada korelasi; dan $\mathrm{r}=0$ artinya korelasi sangan kuat. Korelasi Pearson Product Moment dengan rumus sebagai berikut:

$$
\frac{n \sum X Y-\sum X \sum Y}{\left.\sqrt{\left[n \sum X^{2}\right.}-\left(\sum X\right)^{2}\right]\left[n \sum Y^{2}-\left(\sum Y\right)^{2}\right.}
$$

Jika ingin mengetahui lebuih lanjut signifikan, maka digunakan rumus :

thitung $=\frac{r_{\sqrt{n-2}}}{\sqrt{1-r^{2}}}$

\section{Uji Hipotesis}

Hipotesis dalam penelitian ini adalah: (1) Hipotesis nol (H0) : Tidak terdapat hubungan antara perilaku pencarian informasi mahasiswa dengan penggunaan official account Dakwah Islam; (2) Hipotesis kerja (H1) : Terdapat hubungan antara perilaku pencarian informasi mahasiswa dengan penggunaan official account Dakwah Islam.

Hipotesis diatas dirumuskan kembali menjadi sub-sub hipotesis sebagai berikut: (1) Hipotesis nol (H0) Tidak terdapat hubungan antara dorongan kebutuhan informasi dengan penggunaan official account Dakwah Islam. Hipotesis kerja (H1) Terdapat hubungan antara 
dorongan kebutuhan informasi dengan penggunaan official account Dakwah Islam; (2) Hipotesis nol (H0) Tidak terdapat hubungan antara menciptakan perubahan dengan penggunaan official account Dakwah Islam. Hipotesis kerja (H1) Terdapat hubungan antara menciptakan perubahan dengan penggunaan official account Dakwah Islam; (3) Hipotesis nol (H0) Tidak terdapat hubungan antara adanya aktivitas lingkungan dengan penggunaan official account Dakwah Islam. Hipotesis kerja (H1) Terdapat hubungan antara adanya aktivitas lingkungan dengan penggunaan official account Dakwah Islam.

\section{HASIL DAN PEMBAHASAN}

\section{Analisis Data Penelitian}

Dorongan Kebutuhan Informasi (X1)

Kebutuhan kognitif, kebutuhan ini berkaitan untuk memperkuat atau menambah informasi, pengetahuan , dan pemahaman seseorang akan lingkungannya. Hal ini memang benar bahwa orang menurut pandangan psikologi kognitif mempunyai kecenderungan untuk dapat mengerti dan menguasai lingkungannya. Di samping itu, kebutuhan ini juga dapat memberikan kepuasan atas hasrat keingintahuan dan penyelidikan seseorang (Tan dalam
Yusup, 1995:3).

Dapat dilihat pada Tabel 1 bahwa perilaku pencarian informasi dilakukan untuk memperkuat informasi yang sebelumnya telah dimilki oleh seseorang tersebut, 81 orang menyatakan setuju yang didominasi oleh jenis kelamin perempuan 56 orang dan laki-laki 25 orang, dan untuk 52 orang lainnya menyatakan sangat setuju bahwa pencarian informasi dilakukan untu memperkuat informasi yang sebelumnya telah dimiliki.

Dari Tabel 2, hasil uji Chi-Square antara jenis kelamin dengan dorongan kebutuhan kognitif melakukan pencarian informasi dilakukan untuk memperkuat informasi yang sebelumnya telah dimiliki, dengan $\alpha=10 \%$, derajat percayaan sebesar $90 \%$ dan $\mathrm{df}=4$, Chi-Kuadrat tabel sebesar 7,78 dan Chi-Kuadrat hitung sebesar 8,89 , karena Chi-kuadrat hitung lebih besar daripada Chi-Kuadrat tabel 8,89> 7,78 ,Maka terdapat hubungan yang signifikan antara jenis kelamin dengan melakukan pencarian informasi untuk memperkuat informasi yang sebelumnya telah dimiliki.

Menurut George H. Bodnar (2000:1) Informasi adalah data yang diolah sehingga dapat dijadikan dasar untuk mengambil keputusan atau tindakan-tindakan. Pada dasarnya seorang perilaku pencarian informasi melakukan

TABEL 1. Memperkuat Informasi

\begin{tabular}{ccccccc}
\hline Jenis & $\begin{array}{c}\text { Sangat } \\
\text { Tidak }\end{array}$ & Tidak & & & Sangat & \\
Kelamin & Setuju & Setuju & Netral & Setuju & Setuju & Total \\
\hline Perempuan & 1 & 0 & 11 & 56 & 29 & 97 \\
Laki-laki & 0 & 3 & 4 & 25 & 23 & 55 \\
\hline Total & $\mathbf{1}$ & $\mathbf{3}$ & $\mathbf{1 5}$ & $\mathbf{8 1}$ & $\mathbf{5 2}$ & $\mathbf{1 5 2}$ \\
\hline
\end{tabular}

Sumber : Hasil Pengolahan Data

TABEL 2. Hasil Uji Chi Square

\begin{tabular}{lccl}
\hline & Value & df & Asymp.Sig.(2-sided) \\
\hline Pearson Chi-Square & $8.897^{\mathrm{a}}$ & 4 & 0.064 \\
Likelihood Ratio & 10.051 & 4 & 0.04 \\
Linear-by-linear Association & 0.427 & 1 & 0.513 \\
\hline N of Valid Cases & 152 & & \\
\hline
\end{tabular}


pencarain informasi karena memilki tujuan teretentu, salah satu dorongan untuk melakukan pencarain informasi adalah untuk memperkuat informasi tersebut, karena informasi yang kuat dan jelas serta akurat dapat digunakan dalam mengambil keputusan atau tindakantindakan.

\section{Menciptakan Perubahan (X2)}

Perubahan Alamiah (natural change), Perilaku manusia selalu berubah. Sebagian perubahan itu disebabkan karena kejadian alamiah. Contoh, perubahan perilaku yang disebabkan karena usia seseorang (Sarwono, 2012).

Dilihat dari Tabel 3 bahwa perilaku pencarian informasi dilakukan karena rasa ketakutan memilki pengetahuan kurang, 67 dari repsonden anggota Syamil Unpad menyatakan setuju dan di dominasi oleh anggota yang berusia rentang 19-20, 39 orang beranggapan netral. Kemudian sebanyak 32 orang menyatakan sangat setuju untuk perilaku pencarain informasi dilakukan karena rasa ketakutan memiliki pengethauan kurang, sedangkan yang menjawab tidak setuju berjumlah 7 orang dan sangat tidak setuju 7 orang.
Informasi bisa menjadi fungsi yang sangat penting dalam membantu mengurangi rasa cemas pada seseorang. Menurut pendapat Notoatmodjo (2008) bahwa semakin banyak memiliki informasi dapat mempengaruhi atau menambah pengetahuan terhadap seseorang dan dengan pengetahuan tersebut bisa menimbulkan kesadaran yang akhirnya seseorang itu akan berprilaku sesuai dengan pengetahuan yang dimilikinya.

Kulthau yang dikutip oleh Ishak (2006: 91) menyatakan bahwa kebutuhan informasi muncul akibat kesenjangan pengetahuan yang ada dalam diri seseorang dengan kebutuhan informasi yang diperlukan.

Menurut Krikelas yang dikutip oleh Ishak (2006: 91) mendefinisikan kebutuhan informasi sebagai berikut, "... when the current state of possessed knowledge is less than needed." Krikelas menyatakan bahwa kebutuhan informasi timbul ketika pengetahuan yang dimiliki seseorang kurang dari yang dibutuhkan, sehingga mendorong seseorang untuk mencari informasi.

Dari Tabel 4, hasil uji Chi-Square

TABEL 3. Rasa Ketakutan Memiliki Pengetahuan yang Kurang

\begin{tabular}{ccccccc}
\hline Usia & $\begin{array}{c}\text { Sangat } \\
\text { Tidak }\end{array}$ & Tidak & & & Sangat & \\
(tahun) & Setuju & Setuju & Netral & Setuju & Setuju & Total \\
\hline $17-18$ & 1 & 1 & 5 & 8 & 6 & 21 \\
$19-20$ & 3 & 3 & 22 & 39 & 15 & 82 \\
$21-22$ & 3 & 3 & 11 & 17 & 11 & 45 \\
$23-24$ & 0 & 0 & 1 & 3 & 0 & 4 \\
\hline Total & $\mathbf{7}$ & $\mathbf{7}$ & $\mathbf{3 9}$ & $\mathbf{6 7}$ & $\mathbf{3 2}$ & $\mathbf{1 5 2}$ \\
\hline
\end{tabular}

Sumber : Hasil Pengolahan Data

TABEL 4. Hasil Uji Chi-Square

\begin{tabular}{lccl}
\hline & Value & df & Asymp.Sig.(2-sided) \\
\hline Pearson Chi-Square & $5.236^{\mathrm{a}}$ & 12 & 0.06954 \\
Likelihood Ratio & 6.185 & 12 & 0.906 \\
Linear-by-linear Association & 0.231 & 1 & 0.631 \\
\hline N of Valid Cases & 152 & & \\
\hline
\end{tabular}


antara usia dengan rasa ketakutan memiliki pengetahuan yang kurang, $\alpha=$ $10 \%$, derajat percayaan sebesar $90 \%$ dan $\mathrm{df}=12$, Chi-Kuadrat tabel sebesar 18,5 dan Chi-Kuadrat hitung sebesar 5,2, karena Chi-kuadrat tabel lebih besar daripada Chi-Kuadrat hitung 18,5 > 5,2. Maka tidak terdapat hubungan yang signifikan antara usia dengan melakukan pencarian informasi karena rasa ketakuan memiliki pengetahuan yang kurang. Seseorang akan merasa kekurangan pengetahuan buka karena faktor usia tetapi karena latar belakang aktivitas yang dilakukannya.

\section{Aktivitas Lingkungan}

Aktivitas dalam bahasa Indonesia dapat diartikan sebagai kegiatan, dan lingkungan dalam Kamus Besar Bahasa Indonesia memiliki arti daerah (kawasan dan sebagainya) yang termasuk di dalamnya. Lingkungan merupakan bagian terpenting dan mendasar dari kehidupan manusia. Sejak dilahirkan manusia sudah berada dalam lingkungan baru dan asing baginya. Dari lingkungan baru inilah sifat dan perilaku manusia terbentuk dengan sendirinya. Lingkungan yang baik akan membentuk pribadi yang baik, sementara lingkungan yang buruk akan membentuk sifat dan perilaku yang buruk pula. Anakanak berkembang dari suatu hubungan interaksi antara gerakan-gerakan dalam dan kondisi lingkungan luar.

Faktor lingkungan, meliputi lingkungan kerja (work environment), lingkungan sosial-budaya (socialcultural environment), lingkungan politik-ekonomi (politic-economic environment) mempengaruhi faktor peran sosial maupun faktor kebutuhan individu. Sehingga terjadi pengaruh bertingkat yang akan membentuk kebutuhan informasi. Pencarain informasi dilakukan bukan hanya karena peraturan dilingkungan, tetapi hal lain yang menyebabkan melakukan pencarian informasi karena kebutuhan seseorang sekalipun bukan peraturan dari lingkungan.

Dilihat dari Tabel 5 bahwa perilaku pencarian informasi dilakukan untuk dapat diterima di kelompok diskusi, sebanyak 51 orang setuju dan didominasi oleh angkatan 2015, bahwa kegiatan perilaku pencarain informasi dilakukan untuk dapat bergabung dengan kelompok diskusi, dan 15 orang lainnya menyatakan sangat setuju bahwa pencaraian informasi merupakan salah satu kegiatan untuk dapat diterima di kelompok diskusi, 54 lainnya menjawab netral, sedangkan yang menjawab tidak setuju berjumlah 17 orang dan sangat tidak setuju 15 orang.

Diskusi adalah pertemuan ilmiah untuk bertukar pikiran mengenai suatu masalah,berdiskusi bertukar pikiran. Diskusi merupakan metode pendidikan yang sangat praktis untuk mendapatkan pengeahuan dan meningkatkan kreatifita. Disamping itu diskusi merupakan alat untuk menyamakan persepsi atau cara pandang. Diskusi merupakan bentuk forum ilmiah. Tujuan Diskusi:

(1) Untuk mempertemukan dan menyatukan pendapat, pola fikir dan persepsi dari para

TABEL 5. Untuk dapat Diterima di Kelompok Diskusi

\begin{tabular}{ccccccc}
\hline Angkatan & $\begin{array}{c}\text { Sangat } \\
\text { Tidak }\end{array}$ & Tidak & & & Sangat & \\
Kuliah & Setuju & Setuju & Netral & Setuju & Setuju & Total \\
\hline 2013 & 0 & 0 & 1 & 7 & 1 & 9 \\
2014 & 7 & 7 & 14 & 6 & 6 & 40 \\
2015 & 7 & 7 & 30 & 31 & 6 & 81 \\
2016 & 1 & 3 & 9 & 7 & 2 & 22 \\
\hline Total & $\mathbf{1 5}$ & $\mathbf{1 7}$ & $\mathbf{5 4}$ & $\mathbf{1 5}$ & $\mathbf{1 5}$ & $\mathbf{1 5 2}$ \\
\hline
\end{tabular}

Sumber : Hasil Pengolahan Data 
Balqis Annisa Ramdhani, dkk. Hubungan Perilaku Pencarian Informasi...

anggota kelompok dalam rangka pengambilan keputusan.

(2) Untuk melatih keberanian mengeluarkan pendapat secara sistematis dan logis.

(3) Belajar menerima dan menghargai pendapat orang lain.

(4) Untuk mengubah sikap dan perilaku dan membentuk watak menjadi pribadi yang matang.

(5) Mendapatkan informasi untuk menambah wawasan berpikir.

Faktor yang menyebabkan remaja diterima oleh kelompok teman sebaya yaitu: Kemauan pikir yang meliputi mempunyai inisiatif, banyak memikirkan kepentingan kelompok dan mengemukakan buah pikirannya. Faktor yang menyebabkan remaja ditolak dalam kelompok teman sebaya yaitu Kemampuan pikir meliputi : bodoh sekali atau sering disebut tolol (Rusmini dan Sundari, 2004)

Menurut Erick Erison, bahwa masa remaja terjadi masa krisis, masa pencarian jati diri. Dia berpendapat bahwa penemuan jati diri seseorang didorong oleh sosiokultural.Pergaulan remaja banyak diwujudkan dalam bentuk kelompok-kelompok, baik kelompok besar maupun kelompok kecil. (Sari Yunita, Fenomena dan tantangan Remaja Menjelang Dewasa, Brilliant Books, Yogyakarta, 2011, 30-31)

Dari Tabel 6 Hasil uji Chi-Square antara angkatan kuliah dengan melakukan pencarian informasi untuk dapat diterima di kelompok diskusi , dengan $\alpha=10 \%$, derajat percayaan sebesar $90 \%$ dan $\mathrm{df}=$ 12, Chi-Kuadrat tabel sebesar 18,5 dan Chi-Kuadrat hitung sebesar 20,2, karena Chi-kuadrat hitung lebih besar daripada Chi-Kuadrat tabel 20,2 > 18,5 ,Maka terdapat hubungan yang signifikan antara angkatan kuliah dengan melakukan pencarian informasi dilakukan untuk dapat diterima pada kelompok diskusi. Pada angkatan 2015 dimana rentang usia pada angakatan ini berkisar antara 19 sampai dengan 20 tahun, pada usia 15-20 tahun merupakan dinamika masa kesempurnaan remaja (adolescence proper) dan merupakan puncak perkembangan emosi. Dalam tahap ini terjadi perubahan dari kecenderungan memperhatikan harga diri (Muss. 1968. 27-30).

TABEL 6. Hasil Uji Chi-Square

\begin{tabular}{lccl}
\hline & Value & df & Asymp.Sig.(2-sided) \\
\hline Pearson Chi-Square & $20.267^{\mathrm{a}}$ & 12 & 0.062 \\
Likelihood Ratio & 21.771 & 12 & 0.04 \\
Linear-by-linear Association & 0.008 & 1 & 0.927 \\
\hline N of Valid Cases & 152 & & \\
\hline
\end{tabular}

TABEL 7. Hubungan Antara Perilaku Pencarian Informasi dengan Penggunaan "Official Account Line" Dakwah Islam

\begin{tabular}{|c|c|c|c|}
\hline & & $\begin{array}{l}\text { Perilaku Pencarian } \\
\text { Informasi }\end{array}$ & $\begin{array}{c}\text { Penggunaan Official } \\
\text { Account Line } \\
\text { Dakwah Islam }\end{array}$ \\
\hline \multirow{3}{*}{$\begin{array}{l}\text { Perilaku Pencarian } \\
\text { Informasi }\end{array}$} & Pearson Correlation & 1 & $.433 * *$ \\
\hline & Sig. (2-tailed) & & 0 \\
\hline & $\mathrm{N}$ & 152 & 152 \\
\hline Penggunaan Official & Pearson Correlation & $.433 * *$ & 1 \\
\hline Account Line Dakwah & Sig. (2-tailed) & 0 & \\
\hline Islam & $\mathrm{N}$ & 152 & 152 \\
\hline
\end{tabular}

Sumber : Hasil Pengolahan Data 
Analisis Statistik Inferensial

Hubungan Perilaku Pencarian Informasi dengan Penggunaan Official Account Line Dakwah Islam

Uji Hipotesis :

Hipotesis nol (H0)

Tidak terdapat hubungan perilaku pencarian informasi dengan penggunaan official account Dakwah Islam.

Hipotesis kerja (H1)

Terdapat hubungan perilaku pencarian informasi dengan penggunaan official account Dakwah Islam.

Pada Tabel 7 dapat dilihat koefisien korelasi $\rho=0,433$ dengan koefisien determinasi $\rho 2=0,187$, untuk $\mathrm{dk}=(\mathrm{n}$ -2) 152- $2=150$, untuk melakukan uji signifikan dilakukan perhitungan sebagai berikut :

$$
\begin{aligned}
& \mathrm{t}=\frac{\rho \sqrt{n-2}}{\sqrt{1-\rho^{2}}} \\
& \text { diketahui: } \\
& \mathrm{n}=152 \\
& \mathrm{dk}=(\mathrm{n}-2) \\
& \rho=0,433 \quad \rho 2=0,187 \\
& t_{\text {(hitung) }}=\frac{0,433 \sqrt{152-2}}{\sqrt{1-0,187}} \\
& \quad=5,888
\end{aligned}
$$

Jika $\alpha=0,05$ atau dengan derajat kepercayaan $95 \%$, dan $\mathrm{dk}=150$, maka nilai $\mathrm{t}($ tabel) $=1,655$. Jika $\mathrm{t}$ (hitung) 5,88 lebih besar dari pada $t$ (tabel) 1,655 maka dinyatakan signifikan atau H0 ditolak, artinya perilaku pencarian informasi memiliki hubungan korelasi signifikan dengan penggunaan official account Dakwah Islam.

Koefisien korelasi sebesar 0,433 yang menunjukkan keeratan hubungan perilaku pencarian informasi mahasiswa dengan penggunaan official account line Dakwah Islam, memiliki hubungan yang cukup berarti (Moderate correlation).

Hal ini karena Official Account Line Dakwah Islam merupakan akun official yang dapat memberikan sumber informasi yang dapat di pertanggung jawabkan dengan secara akurat sesuai dengan hadist dan al-Quran, dengan

\begin{tabular}{|c|c|}
\hline $\begin{array}{l}\text { Hubungan } \\
\text { Informasi }\end{array}$ & $\begin{array}{l}\text { Dorongan } \\
\text { dengan }\end{array}$ \\
\hline
\end{tabular}
adanya fasilitas konsultasi langsung dengan Ustadz atau pemateri dapat memberikan informasi sesuai dengan yang diharapkan oleh pengguna, penyampaian berita dan informasi yang dikemas secara menarik dengan dukungan aplikasi Line. Uji Hipotesis :

Hipotesis nol (H0)

Tidak terdapat hubungan antara dorongan kebutuhan informasi dengan penggunaan official account Dakwah Islam.

Hipotesis kerja (H1)

Terdapat hubungan antara dorongan

\begin{tabular}{|c|c|c|c|}
\hline & & $\begin{array}{c}\text { Penggunaan Official } \\
\text { Account Line Dakwah } \\
\text { Islam }\end{array}$ & $\begin{array}{c}\text { Dorongan } \\
\text { Kebutuhan } \\
\text { Informasi }\end{array}$ \\
\hline \multirow{3}{*}{$\begin{array}{l}\text { Penggunaan Official } \\
\text { Account Line Dakwah } \\
\text { Islam }\end{array}$} & Pearson Correlation & 1 & $.379 * *$ \\
\hline & Sig. (2-tailed) & & 0 \\
\hline & $\mathrm{N}$ & 152 & 152 \\
\hline \multirow{3}{*}{$\begin{array}{l}\text { Dorongan Kebutuhan } \\
\text { Informasi }\end{array}$} & Pearson Correlation & $.379 * *$ & 1 \\
\hline & Sig. (2-tailed) & 0 & \\
\hline & $\mathrm{N}$ & 152 & 152 \\
\hline
\end{tabular}
kebutuhan informasi dengan penggunaan official account Dakwah Islam.

Pada Tabel 8 dapat dilihat koefisien korelasi $\rho=0,379$ dengan koefisien

TABEL 8. Hubungan Dorongan Kebutuhan Informasi dengan Penggunaan "Official Account Line" Dakwah Islam

Sumber : Hasil Pengolahan Data 
Balqis Annisa Ramdhani, dkk. Hubungan Perilaku Pencarian Informasi...

determinasi $\rho^{2}=0,143$, untuk $\mathrm{dk}=(\mathrm{n}$ -2) 152- $2=150$, untuk melakukan uji signifikan dilakukan perhitungan sebagai berikut:

$$
\begin{aligned}
& \mathrm{t}=\frac{\rho \sqrt{n-2}}{\sqrt{1-\rho^{2}}} \\
& \text { diketahui: } \\
& \mathrm{n}=152 \\
& \mathrm{dk}=(\mathrm{n}-2) \\
& \rho=0,433 \quad \rho 2=0,187 \\
& t_{\text {(hitung) }}=\frac{0,433 \sqrt{152-2}}{\sqrt{1-0,187}} \\
& =5,888
\end{aligned}
$$

Jika $\alpha=0,05$ atau dengan derajat kepercayaan $95 \%$, dan $\mathrm{dk}=150$, maka nilai $\mathrm{t}$ (tabel) $=1,655$. Jika $\mathrm{t}$ (hitung) 5,017 lebih besar dari pada $\mathrm{t}$ (tabel) 1,655 , maka dinyatakan signifikan atau $\mathrm{H} 0$ ditolak, artinya dorongan kebutuhan informasi memiliki hubungan korelasi signifikan dengan penggunaan official account line Dakwah Islam.

Koefisien korelasi sebesar 0,379 yang menunjukkan keeratan hubungan dorongan kebutuhan informasi dengan penggunaan official account line Dakwah Islam, memiliki hubungan yang kecil (Low correlation).

Hal ini karena dorongan kebutuhan informasi tidak hanya menggunakan Official Account Line Dakwah Islam sebagai media pemenuhan kebutuhan informasi, tetapi dapat menggunakan literatur buku, jurnal, e-book dan media internet, sehingga hubungan yang terdapat pada dorongan kebutuhan informasi dengan penggunaan official account line Dakwah Islam berhubungan rendah.

\section{Hubungan Menciptakan Perubahan dengan Penggunaan Official Account Line Dakwah Islam}

Uji Hipotesis :

Hipotesis nol (H0)

Tidak terdapat hubungan antara menciptakan perubahan dengan penggunaan official account Dakwah Islam.

Hipotesis kerja (H1)

Terdapat hubungan antara menciptakan perubahan dengan penggunaan official account Dakwah Islam.

Pada Tabel 9 dapat dilihat koefisien korelasi $\rho=0,480$ dengan koefisien determinasi $\rho 2=0,230$, untuk $\mathrm{dk}=(\mathrm{n}$

\begin{tabular}{|c|c|c|c|}
\hline & & $\begin{array}{c}\text { Penggunaan Official } \\
\text { Account Line Dakwah } \\
\text { Islam }\end{array}$ & $\begin{array}{c}\text { Menciptakan } \\
\text { Perubahan }\end{array}$ \\
\hline \multirow{3}{*}{$\begin{array}{l}\text { Penggunaan Official } \\
\text { Account Line Dakwah } \\
\text { Islam }\end{array}$} & Pearson Correlation & 1 & $.480^{* *}$ \\
\hline & Sig. (2-tailed) & & 0 \\
\hline & $\mathrm{N}$ & 152 & 152 \\
\hline \multirow{3}{*}{$\begin{array}{l}\text { Menciptakan } \\
\text { Perubahan }\end{array}$} & Pearson Correlation & $.480 * *$ & 1 \\
\hline & Sig. (2-tailed) & 0 & \\
\hline & $\mathrm{N}$ & 152 & 152 \\
\hline
\end{tabular}
-2) 152- $2=150$, untuk melakukan uji signifikan dilakukan perhitungan sebagai berikut:

$$
\begin{aligned}
& \mathrm{t}=\frac{\rho \sqrt{n-2}}{\sqrt{1-\rho^{2}}} \\
& \text { diketahui : } \\
& \mathrm{n}=152 \\
& \mathrm{dk}=(\mathrm{n}-2) \\
& \rho=0,480 \quad \rho^{2}=0,230 \\
& t_{\text {(hitung) }}=\frac{0,480 \sqrt{152-2}}{\sqrt{1-0,230}}=6,702 \\
& \text { Jika } \alpha=0,05 \text { atau dengan derajat } \\
& \text { kepercayaan } 95 \% \text {, dan dk=150, maka } \\
& \text { nilai t (tabel) }=1,655 \text {. Jika } \text { (hitung) } 6,702
\end{aligned}
$$

TABEL 9. Hubungan Menciptakan Perubahan dengan

Penggunaan "Official Account Line" Dakwah Islam

Sumber : Hasil Pengolahan Data 
lebih besar dari pada t (tabel) 1,655, maka dinyatakan signifikan atau H0 ditolak, artinya menciptakan perubahan memiliki hubungan korelasi signifikan dengan penggunaan official account line Dakwah Islam.

Koefisien korelasi sebesar 0,480 yang menunjukkan keeratan hubungan menciptakan perubahan dengan penggunaan official account line Dakwah Islam, memiliki memilki hubungan yang cukup berarti (Moderate correlation)

Hal ini karena menciptakan perubahan baik perubahan secara alamiah , perubahan terencana dan kesedian untuk berubah, karena ada rasa malu memilki sedikit pengetahuan sehingga adanya perubahan secara alamiah, melakukan pencarian informasi untuk perubahan masa depan dan perubahan dilingkungan dapat sebagai indikator adanya hubungan yang cukup antara menciptakan perubahan dengan penggunaan official account line Dakwah Islam. Informasi bisa menjadi fungsi yang sangat penting dalam membantu mengurangi rasa cemas pada seseorang. Menurut pendapat Notoatmodjo (2008) bahwa semakin banyak memiliki informasi dapat mempengaruhi atau menambah pengetahuan terhadap seseorang dan dengan pengetahuan tersebut bisa menimbulkan kesadaran yang akhirnya seseorang itu akan berprilaku sesuai dengan pengetahuan yang dimilkinya.
Hubungan Aktivitas Lingkungan dengan Penggunaan "Official Account Line" Dakwah Islam

Uji Hipotesis :

Hipotesis nol (H0)

Tidak terdapat hubungan antara aktivitas lingkungan dengan penggunaan official account Dakwah Islam.

Hipotesis kerja (H1)

Terdapat hubungan antara aktivitas lingkungan dengan penggunaan official account Dakwah Islam.

Pada Tabel 10 dapat dilihat koefisien korelasi $\rho=0,703$ dengan koefisien determinasi $\rho^{2}=0,494$, untuk $\mathrm{dk}=(\mathrm{n}$ -2) 152- $2=150$, untuk melakukan uji signifikan dilakukan perhitungan sebagai berikut:

$$
\begin{aligned}
& \mathrm{t}=\frac{\rho \sqrt{n-2}}{\sqrt{1-\rho^{2}}} \\
& \text { diketahui : } \\
& \mathrm{n}=152 \\
& \mathrm{dk}=(\mathrm{n}-2) \\
& \rho=0,480 \rho^{2}=0,230 \\
& t_{\text {(hitung) }}=\frac{0,703 \sqrt{152-2}}{\sqrt{1-0,494}} \\
& \quad=12,101
\end{aligned}
$$

Jika $\alpha=0,05$ atau dengan derajat kepercayaan $95 \%$, dan $\mathrm{dk}=150$, maka nilai $\mathrm{t}$ (tabel) $=1,655$. Jika $\mathrm{t}$ (hitung) 12,101 lebih besar dari pada $\mathrm{t}$ (tabel) 1,655 maka dinyatakan signifikan atau H0 ditolak, artinya aktivitas lingkungan memiliki hubungan korelasi signifikan dengan penggunaan official account line Dakwah Islam.

TABEL 10. Hubungan Aktivitas Lingkungan dengan Penggunaan "Official Account Line" Dakwah Islam

\begin{tabular}{llcc}
\hline & & $\begin{array}{c}\text { Penggunaan Official } \\
\text { Account Line Dakwah } \\
\text { Islam }\end{array}$ & $\begin{array}{c}\text { Aktivitas } \\
\text { Lingkungan }\end{array}$ \\
\hline Penggunaan Official & Pearson Correlation & 1 & $.703^{* *}$ \\
Account Line Dakwah & Sig. (2-tailed) & 152 & 0 \\
Islam & $\mathrm{N}$ & $.703^{* *}$ & 152 \\
\hline \multirow{3}{*}{ Aktivitas Lingkungan } & Pearson Correlation & 0 & 1 \\
& Sig. (2-tailed) & 152 & 152 \\
\hline
\end{tabular}

Sumber : Hasil Pengolahan Data 
Koefisien korelasi sebesar 0,703 yang menunjukkan keeratan aktivitas lingkungan dengan penggunaan official account line Dakwah Islam, memiliki hubungan yang kuat (High correlation).

Faktor lingkungan, meliputi lingkungan kerja (work environment), lingkungan sosial-budaya (socialcultural environment), lingkungan politik-ekonomi (politic-economic environment) mempengaruhi faktor peran sosial maupun faktor kebutuhan individu. Sehingga terjadi pengaruh bertingkat yang akan membentuk kebutuhan informasi. Pencarian informasi dilakukan bukan hanya karena peraturan dilingkungan, tetapi hal lain yang menyebabkan melakukan pencarian informasi karena kebutuhan seseorang sekalipun bukan peraturan dari lingkungan. Lingkungan anggota Syamil Unpad bergerak pada orientasi Dakwah dan Ilmu agama Islam sehingga dapat berhubungan kuat dengan penggunaan official account line Dakwah Islam.

\section{SIMPULAN}

Dari hasil keseluruhan setelah melakukan penelitian, dapat disimpulkan bahwa terdapat hubungan antara perilaku pencarian informasi mahasiswa anggota Syamil Unpad dengan penggunaan official account line Dakwah Islam. Berikut adalah penjabaran dari hasil penelitian ini: (1) Terdapat hubungan yang signifikan antara perilakau pencarian informasi mahasiswa anggota Syamil Unpad dengan penggunaan official account line Dakwah Islam. Hasil penelitian menunjukkan bahwa penggunaan official account line Dakwah Islam karena macam isi informasi yang tersedia dan dan sebagai sumber informasi yang jelas, akurat dan dapat dipertanggung jawabkan isinya dengan memilik tingkat keeratan hubungan cukup berarti (Moderate correlation); (2) Terdapat hubungan yang signifikan antara dorongan kebutuhan informasi mahasiswa anggota Syamil Unpad dengan penggunaan official account line Dakwah Islam. Hasil penelitian menunjukkan bahwa dorongan kebutuhan kognitif, kebutuhan afektif, kebutuhan integrasi personal, kebutuhan integrasi sosial dan kebutuhan berkhayal, dorongan kebutuhan informasi tersebut digunakan untuk pemenuhan kebutuhan informasi namun penggunaan official account line Dakwah Islam bukan menjadi satu-satunya media pemenuhan kebutuhan informasi sehingga memilki tingkat keeratan hubungan yang rendah (Low correlation); (3) Terdapat hubungan yang signifikan menciptakan perubahan pada mahasiswa anggota Syamil Unpad dengan penggunaan official account line Dakwah Islam. Hasil penelitian menujukan bahwa perubahan seacara alamiah, perubahan terencana, dan kesedian untuk berubah merupakan tujuan dari kegiatan perilaku pencarian informasi pada mahasiswa anggota Syamil Unpad dengan penggunaan official account line Dakwah Islam sebagai media pencarian informasi, sehingga memiliki hubungan yang cukup berarti (Moderate Correlation); (4) Terdapat hubungan yang signifikan aktivitas lingkungan mahasiswa Syamil Unpad dengan penggunaan official account line Dakwah Islam. Hasil penelitian menujukan bahwa aktivitas lingkungan Syamil Unpad mendukung untuk menggunakan official account line Dakwah Islam karena sesuai dengan aktivitas kegiatan mahasiswa Syamil Unpad yaitu melakukan Dakwah dan mempelajari Ilmu Agama Islam, sehingga memilki hubungan yang kuat (High Correlation).

Dari penelitian yang bertajuk dengan penggunaan official account line Dakwah Islam. Penulis tidak lupa untuk memberikan beberapa saran diantaranya: (1) Sebaiknya perilaku pencarian informasi mahasiswa anggota Syamil Unpad tidak hanya dilakukan pada media sosial official account line Dakwah Islam saja, dapat menggunakan media lain seperti e-book, instagram dan media cetak atau media komunikasi informasi 
lainnya dalam pemenuhan kebutuhan informasi mahasiwa anggota Syamil Unpad; (2) Sebaiknya official account line Dakwah Islam lebih memiliki inovasi tampilan dalam memberikan informasi yang menarik dan jenis informasi yang berankeragam sehingga pengguna dapat terepnuhi kebutuhan informasinya ketika melakukan pencarian informasi.

\section{DAFTAR PUSTAKA}

Arikunto, S. (1993). Metode Penelitian. Yogyakarta: Pustaka Belajar.

Azwar, S. (2009). Sikap Manusia Teori dan Pengukuran. Yogyakarta: Pustaka Pelajar.

Efendi, O. U. (2003). Ilmu Teori dan Filsafat Komunikasi. Bandung: Citra Aditya Bakti.

Moh, N. (2003). Metode Penelitian. Cetakan Kelima. Jakarta : Ghalia Indonesia.

Mulyana, D. (2001). Metodologi Penelitian Kualitatif. BANDUNG: ROSDA KARYA.

Nur, I. S., \& Meilia. (2010). Statistika Deskriptif dan Induktif. Yogyakarta: Graha Ilmu.

Prijana. (2005). Metode Sampling Terapan. Bandung: Penerbit Buku Pendidikan.

Prijana, Winoto, Y., \& Yanto, A. (2016). Metode Penelitian Kuantitatif. Bandung: UNPAD PRESS.

Rakhmat, J. (2004). Psikologi Komunikasi. Bandung: Remaja Rosda Karya.

Rakhmat, J. (2012). Metode Penelitian
Komunikasi. Bandung: Remaja Rosda Karya.

Riduwan. (2009). Pengantar Statistika Sosial. Bandung: Alfabeta.

Rusmini, S., \& Sundari, S. (2004). Perkembangan Anak dan Remaja. Jakarta: Rineka Cipta.

Saepudin, E. (2009). Perilaku Pencarian dalam Memenuhi Kebutuhan Informasi. Perilaku Pencarian dalam Memenuhi Kebutuhan Informasi, 1-2.

Safaria, T., \& Saputra, E. (2009). Manajemen Emosi (Sebuah Panduan Cerdas Bagaimana Mengelola Emosi Positif dalam Hidup Anda. Jakarta: Bumi Aksara.

Sarwono, W. S. (2012). Psikologi Remaja. Depok: Raja Grafindo Persada.

Senjaya, S. D. (2007). Teori Komunikasi Edisi 2. Jakarta: Universitas Terbuka.

Siregar, S. (2011). Statistika Deskriptif untuk Penelitian. Jakarta: Rajawali Pers.

Sutanta, E. (2003). Sistem Informasi Manejemen. Yogyakarta: Graha Ilmu.

West, R., \& Lynn, H. T. (2008). Teori Komunikasi Analisi dan Aplikasi. Jakarta: Salemba Humanika.

Yakub. (2012). Pengantar Sistem Informasi. Yogyakarta: Graha Ilmu.

Yusup, M Pawit. (1995). Pedoman Parktis Mencari Informasi. Bandung: Remaja Rosda Karya.

Yusup, M. P., \& Subekti, P. (2010). Teori dan Praktek Penelusuran Informasi. Jakarta: Kencana Prenada Media Group. 